Justyna Szlaużys

Uniwersytet w Białymstoku

E-MAIL: justyna.murawko13@gmail.com

\title{
Leśne przedszkole jako alternatywna forma wczesnej edukacji
}

\begin{abstract}
STRESZCZENIE
Leśne przedszkola są alternatywną formą wczesnej edukacji, która odbywa się w przestrzeni lasu z wykorzystaniem dostępnych w przyrodzie, naturalnych materiałów edukacyjnych. Dzięki bliskiemu kontaktowi z naturą dzieci rozwijają zdolności motoryczne, wrażliwość polisensoryczną, pomysłowość i umiejętność kontemplatywnej i krytycznej obserwacji, samodyscyplinę i współpracę. Celem artykułu jest wywołanie refleksji nad poszukiwaniem inicjatyw edukacyjnych poszerzających relację dziecka ze światem przyrody.

SŁOWA KLUCZOWE: edukacja przedszkolna, natura, dziecko, las
\end{abstract}

\section{Wstęp}

W ciągu ostatnich kilku dziesięcioleci radykalnie zmienił się sposób rozumienia i doświadczania przyrody przez dzieci, które dzięki edukacji medialnej posiadają wiedzę na temat globalnych zagrożeń i postępującej degradacji środowiska naturalnego, ale ich relacje z naturą nie opierają się na bezpośrednim doświadczeniu, lecz mają wyobrażeniowy charakter. Dorośli w trosce o bezpieczeństwo najmłodszych budują w nich przekonanie, że kontakt z przyrodą jest niebezpieczny, „uczą” unikania, indukują w dzieciach strach i obawy. Powodowani lękiem pozbawiają dzieci tego, czego sami za młodu doświadczali w bardzo pozytywnym sensie. Obcując bezpośrednio z naturą, dziecko doświadcza świata intensywnie i wyjątkowo: zbaczając z utartych ścieżek, znajdując nowe, nieodkryte miejsca, wydeptując bazy w polach, wchodząc na drzewo, wisząc głową w dół, wspinając się na najwyższe gałęzie przeżywa przygody tworzące najbardziej ekscytujące wspomnienia dzieciństwa. Dziś świat natury próbuje się zastąpić technologią. Jednak najdoskonalszy program edukacyjny i obraz o największej rozdzielczości nie zastąpi żywego drzewa. Komputerowe efekty nie przybliżają do tajemnic przyrody, lecz zacierają granice między tym, co żywe: człowiekiem, zwierzęciem i rośliną a maszyną, która wszystko zamienia w obrazy. Jako społeczeństwo coraz mniej czasu 
spędzamy w plenerze. Skutkuje to ograniczeniem bogactwa ludzkiego doświadczenia, zmysły ulegają fizjologicznemu i psychologicznemu otępieniu, dostosowują się do innego rodzaju rzeczywistości. Zapominamy przy tym, że jesteśmy częścią ekosystemu. Oderwanie od natury zagraża naszemu zdrowiu. Dzieciństwo spędzone w domu, w otoczeniu nowinek technologicznych, „wyjaławia” dzieci i wpływa negatywnie na ich rozwój psychiczny, emocjonalny i fizyczny (Louv, 2014). Brak kontaktu z przyrodą, a stąd ambiwalentny, a czasami wrogi stosunek do niej, zagraża również miejscom, w których żyjemy. Decyzje podejmowane w przyszłości przez ludzi, którzy stracili więź z naturą, mogą negatywnie wpłynąć na przyszłość ludzkości. Zjawisko to już obserwujemy w krajach wysokorozwiniętych, gdzie tylko nieliczne głosy rozsądku wzywają do zrównoważonego rozwoju z poszanowaniem ekosystemu, w którym żyjemy. Jeśli więc równowaga zależy od przekształcenia relacji człowieka ze środowiskiem, właściwa edukacja ekologiczna jawi się jako jedno z najpoważniejszych wyzwań naszych czasów. Idea leśnych przedszkoli jako alternatywna forma wychowania jest jedną z najcenniejszych, moim zdaniem, inicjatyw mających na celu odzyskanie autentycznych relacji człowieka ze światem przyrody.

Celem artykułu jest wywołanie refleksji nad poszukiwaniem inicjatyw edukacyjnych poszerzających relację dziecka z naturą. W pierwszej części artykułu pragnę przedstawić leśne przedszkola jako alternatywną formę wczesnej edukacji, w drugiej omówię pokrótce ich historię oraz polskie doświadczenia związane $\mathrm{z}$ koncepcjami wychowania przez kontakt z przyrodą, a także założenia edukacji ekologicznej. Następnie przybliżę koncepcje i formy oddziaływań edukacyjnych realizowane w leśnych przedszkolach. W zakończeniu podejmę próbę krytycznego spojrzenia na prezentowany model kształcenia alternatywnego.

\section{Leśne przedszkola jako alternatywna forma wczesnej edukacji}

We wczesnej edukacji można wyróżnić trzy etapy: niemowlęcy, poniemowlęcy oraz przedszkolny (Czub i Appelt, 2013). Poniższy artykuł dotyczy okresu przedszkolnego, tj. wieku od 4. do 6.-7. roku życia. Znaczenie terminu „Wczesna edukacja” przyjmuję za Eugenią Potulicką (2014) i rozumiem jako wszystkie rodzaje edukacji przed rozpoczęciem nauki szkolnej, organizowane przez różne instytucje: żłobki, centra opieki, ogródki dziecięce, przedszkola oraz inne, wktórych rozwój i uczenie się dzieci są ujmowane holistycznie, a opieka jest traktowana jak integralna część procesu edukacyjnego.

Pojęcia alternatywności w odniesieniu do edukacji używa się na określenie placówek lub działań edukacyjnych istniejących poza dominującym, 
konwencjonalnym typem szkół czy form kształcenia. Zdaniem Bogusława Śliwerskiego

edukacja alternatywna [...], aby mogła zaistnieć, musi najpierw spełnić warunek negatywny poprzez rozpoznanie w obszarze swojej rzeczywistości tego, czego pedagodzy nie zamierzają kontynuować lub uwzględniać w swojej własnej działalności (Śliwerski, 2011, cyt za: Zamojska, 2012, s. 110).

Dzięki temu pedagogika alternatywna spełnia trzy istotne funkcje: funkcję kompensacyjną - wypełniającą braki w istniejących typach szkół, zaspokajającą te potrzeby, których nie zaspokajają szkoły tradycyjne; funkcję dywersyfikacyjną - realizującą społeczną ideę pluralizmu edukacyjnego, oraz funkcję innowacyjną - najważniejszą, związaną z tworzeniem obszaru możliwości realizowania eksperymentów i innowacji pedagogicznych (Śliwerski, 2010, s. 452).

Leśne przedszkola to placówki edukacyjne, gdzie forma kształcenia jest odmienna niż w placówkach tradycyjnych, państwowych. Powodem ich powstawania jest niezadowolenie wynikające z ograniczeń tradycyjnej edukacji przedszkolnej oraz chęć wprowadzenia nowych, atrakcyjnych elementów, postrzeganych jako wartościowe pod względem wychowawczym. Do głównych założeń edukacji alternatywnej należy humanizacja edukacji, wprowadzenie form percepcyjno-innowacyjnych zastępujących formy percepcyjno-odtwórcze, wprowadzenie programu rozwijającego aktywność dzieci. Placówki alternatywne cechują się większą autonomią i samorządnością niż przedszkola publiczne, funkcjonują w głównej mierze z pieniędzy wpłacanych przez rodziców i w mniejszym stopniu z wpłat fundacji oraz darowizn. Barierą w dostępie do tej formy edukacji jest niestety wysokość czesnego. Zasady wychowania i program nauczania ustalane są przez organizatorów placówek, muszą jednak spełniać wymagania formalne, tak aby wpisać się w ramy prawa oświatowego. Leśne przedszkola, podobnie jak szkoły alternatywne, tworzą warunki wszechstronnej edukacji, charakteryzują się stosowaniem metod aktywizujących i prowokujących podopiecznych do samodzielności, co sprzyja efektywności procesu kształcenia (por. Zalewska, 2013).

Peter Jarvis (2001), dokonując analizy sytuacji, w jakich zachodzi zjawisko uczenia się, zaproponował podział na dwa obszary: uczenie się planowane oraz incydentalne. Leśne przedszkole, oprócz realizacji treści programowych, inicjuje liczne możliwości pozaplanowego uczenia się w sytuacjach formalnych, nie zawsze edukacyjnych, a zwłaszcza uczenia się „Z" i „w” codzienności. Sharan Merriam i Ralh Brocket (2007) zauważają, że edukacja nie może istnieć bez uczenia się, natomiast zjawisko uczenia się występuje przede wszystkim poza kontekstem edukacyjnym (za: Muszyński, 2014). 


\section{Historia leśnych przedszkoli}

Kluczowym zadaniem pedagogów jest wszechstronne wspieranie rozwoju dziecka, czemu służy, między innymi, poszukiwanie innowacji. Leśne przedszkole jest alternatywnym rozwiązaniem sprzyjającym rozwijaniu współcześnie akceptowanych, cenionych kompetencji i umiejętności, takich jak: kreatywność, samodzielność i umiejętność krytycznego myślenia (por. Janik, 2015, s. 133).

Koncepcje wychowania przez kontakt z naturą pojawiły się w Polsce w latach dwudziestych XX wieku. Wacław Sonelski i Artur Magiera (2016) poddali analizie teksty Marii Rodziewiczówny (Lato leśnych ludzi), Franciszka Wysłoucha (Ślizgawka) oraz Mariusza Zaruskiego (Na bezdrożach tarzańskich), dowodząc, że doskonale wpisują się one w nurt wychowania przez przygodę, której tłem jest dzika przyroda. Idea ta stanowi również podstawowe założenie formacyjne harcerstwa polskiego. Powrót do natury w ramach wychowania przedszkolnego stanowi kontynuację tych, niezwykle cennych, oddziaływań edukacyjnych.

W Niemczech tradycja leśnych przedszkoli liczy przeszło sześćdziesiąt lat, w Polsce tego rodzaju inicjatywy nie zyskały jeszcze należytego uznania w gronie praktyków i teoretyków kształcenia.

Idea leśnych przedszkoli pojawiła się w roku 2010 na Kaszubach w Brodnicy Górnej, a w roku 2014 na Żywiecczyźnie zorganizowano pierwsze Przedszkole Leśne. Rok później, w październiku 2015 roku, powstało w Białymstoku Przedszkole Leśne „Puszczyk” powołane z inicjatywy rodziców. Koncepcja organizacyjna tego typu placówek zakłada, że 80\% czasu pobytu w placówce dzieci spędzają na świeżym powietrzu (Janik, 2015).

Obecnie w naszym kraju oficjalnie istnieją 34 leśne przedszkola, natomiast nie wszystkie faktycznie działają. Po weryfikacji tych danych na mapie Polski odnotowujemy 29 realnych inicjatyw o takim charakterze, a cztery przedszkola opierają swój program na elementach przedszkoli leśnych (Christ, 2018).

Koncepcja leśnych przedszkoli doskonale umiejscawia się w polskiej myśli pedagogicznej, mimo to założenia tych placówek nie do końca są znane i spopularyzowane. Teoria outdoor education, experimental education, adventure education oraz pedagogika przeżycia Kurta Huhna stanowią nowość w polskim dyskursie pedagogicznym. Pomijając pedagogikę przeżycia, reszta konceptów nie pojawia się w polskiej literaturze przedmiotu. Pierwsze polskie publikacje podejmujące ten temat, autorstwa Ewy Palamer-Kabacińskiej, Agnieszki Leśny oraz Agnieszki Bąk, dotyczyły pedagogiki przygody i zostały opublikowane w latach 2012-2014. Polski czytelnik miał okazję poznać 
jedynie odpowiedniki outdoor education w postaci edukacji przygodowej, edukacji środowiskowej, edukacji w przyrodzie i pedagogiki przygody. Koncepcja leśnych przedszkoli posiada również źródła w teoriach, które na dobre zakorzeniły się w polskiej myśli humanistycznej. Należą do nich teorie Johna Deweya, Jeana Piageta czy Lwa Wygotskiego dające początek procesom uczenia się, które ukazują dziecko jako jednostkę budującą wiedzę na temat świata w drodze swych kontaktów z otoczeniem (Janik, 2015, s. 133).

Historia leśnych przedszkoli rozpoczęła się w 1954 roku, w niewielkim duńskim miasteczku, gdzie Elle Flateuem zainspirowała grupę innych rodziców tym, że każdego dnia wraz ze swymi dziećmi spacerowała do lasu. Obecnie „Skovbornehave” - leśne przedszkola - stanowią 10\% wszystkich placówek przedszkolnych w tym kraju. W kolejnych latach idea ta przekroczyła granicę krajów skandynawskich i dotarła między innymi do Niemiec, gdzie Ursula Suben otworzyła pierwsze niemieckie leśne przedszkole w Wiesbaden w 1968 roku. Przedszkole to nie dostało oficjalnej rekomendacji władz i w dalszych latach funkcjonowało w zakresie prywatnym, bez dofinansowań, opłacane przez rodziców. W 1991 roku Petra Jäger i Kerstin Jebsen zainspirowane założeniami duńskich przedszkoli wydały czasopismo pedagogiczne „Spielen und Lernen”, w którym przedstawiły projekt „Przedszkola bez drzwi i ścian”. Nowo powstała koncepcja pedagogiczna była początkiem utworzenia leśnego przedszkola we Flensburgu w 1993 roku. Wraz z upływem kolejnych lat popularność tych placówek znacznie wzrosła. W 2005 roku w samych Niemczech funkcjonowało ponad 450 leśnych przedszkoli, a wg danych nieoficjalnych blisko 800 . W Danii liczba leśnych przedszkoli to około 80 placówek. Koncepcja ta dotarła również do Wielkiej Brytanii, Austrii, Szwajcarii, Czech, a także Stanów Zjednoczonych (Janik, 2015). W wypadku naszych południowych sąsiadów, Czech, w okresie kilku kolejnych lat powstało sto dwadzieścia leśnych przedszkoli, na terenie całego kraju, a ogólne poparcie dla tego rodzaju edukacji spowodowało zmiany ustawowe o edukacji przedszkolnej i nadanie prawnego statusu tym inicjatywom. Uważam, że jest to przykład godny naśladowania.

\section{W kierunku leśnej edukacji}

Mimo że w Polsce leśne przedszkola z trudem budują swoją pozycję na rynku edukacyjnym, jako kraj możemy się pochwalić blisko 30-letnią tradycją działań uświadamiających społeczeństwu rolę lasu jako elementu środowiska kształtującego nasz dobrostan. Co prawda przez wiele lat edukacja leśna kojarzona była z edukacją formalną, prowadzoną przez szkołę, taką jak technika leśne i wydziały leśne wyższych uczelni, gdzie kształcono przyszłych leśników, jednak w roku 1994 powołano leśne kompleksy promocyjne, a nadleśnictwom 
promocyjnym przydzielono zadania w nieformalnym zakresie. Edukacja leśna społeczeństwa jest jednym z podstawowych zadań, jakie są realizowane przez Lasy Państwowe. Zadanie to wynika z założeń „Polityki leśnej państwa” i przyjętych „Kierunków rozwoju edukacji leśnej społeczeństwa w Lasach Państwowych". Edukacja leśna ma za zadanie upowszechnienie wiedzy na temat środowiska i gospodarki leśnej, zbudowanie społecznego zaufania wobec zawodu leśnika oraz kreowanie postaw służących odpowiedniemu i racjonalnemu korzystaniu ze wszystkich funkcji lasu.

Edukacja leśna jest składową edukacji ekologicznej, stanowiącą rozległą dziedzinę, obejmującą także tematy z zakresu ochrony środowiska, takie jak: zdrowy tryb życia, szacunek wobec surowców naturalnych zużywanych przez człowieka, budowanie konstruktywnych zachowań i postaw wobec przyrody żywej i nieożywionej (Chrzanowski, 2003, s. 5).

Edukacja ekologiczna posiada różnorodne cele, eksponowane zależnie od koncepcji autora opisującego ją w swej publikacji. Pojęcie edukacji ekologicznej zostało wystandaryzowane w deklaracji pokonferencyjnej ONZ z tzw. Szczytu Ziemi w Rio de Janeiro w roku 1992. Dokument zaleca nauczanie podstaw zrównoważonego gospodarowania środowiskiem naturalnym oraz kształtowanie umiejętności holistycznego myślenia, w celu rozumienia potrzeb człowieka i przyrody. Dokument formułuje cele wychowawcze, które odnoszą się do kreowania proekologicznych postaw, kształtowania pożądanych cech osobowościowych, widocznych w postępowaniu i przekonaniach, w szacunku dla własnego życia, w podnoszeniu własnej kultury osobistej i ekoetyki, budowaniu szacunku wobec dziedzictwa kulturowego i przyrodniczego, empatii wobec cierpienia zwierząt, wrażliwości na ład przestrzenny i piękno przyrody, budzeniu uczuć i emocji przyjaznych dla środowiska, kształtowaniu pozytywnych zachowań i reakcji uczniów.

W warunkach idealnych nauka ekologicznego myślenia powinna zaczynać się w domu rodzinnym, od najmłodszych lat życia dziecka. Jednak aby stała się ona powszechna, trzeba już teraz zacząć wychowywać - najlepiej już na poziomie przedszkola - przyszłych świadomych i kochających przyrodę rodziców. Przedszkole rozpoczyna etap edukacji ekologicznej, tworząc podwaliny do dalszego kształcenia w tym zakresie. Działania edukacyjno-wychowawcze wiążą się z nakładami finansowymi. Najlepsze działania proekologiczne generują maksymalne efekty przy minimalnych nakładach. Dlatego las wydaje się doskonałym miejscem prowadzenia edukacji ekologicznej - jest to najtańsza i najlepiej wyposażona "pracownia dydaktyczna” (Jakubowska, 2008).

Według W. Okonia edukacja ekologiczna, tak samo jak każdy inny rodzaj edukacji, jest procesem kształcenia zawierającym uczenie się i nauczanie oraz 
kształtowanie ucznia z jego własnym, podmiotowym udziałem, realizowanie celowych zmian w jego osobowości (Okoń, 1996, s. 129).

Rozwijanie indywidualności i osobowości każdego ucznia jest głównym celem edukacji. Ukształtowanie w uczniach pozytywnego, emocjonalnego stosunku wobec ludzi i otaczającej przyrody, a także umiejętności poznawania świata i użycie do tego odpowiednich technik, narzędzi i metod, należy do podstawowych celów edukacji ekologicznej.

W nurcie edukacji ekologicznej leśne przedszkola pełnią szczególną rolę. Stanowią przestrzeń pomagającą wychować dzieci w zgodzie z naturą i jej cyklicznością. Są miejscem, które pozwala zdobyć nową wiedzę i umiejętności, kształtuje szacunek do środowiska naturalnego, historycznego i kulturowego. Charakterystycznym atutem leśnego przedszkola jest całkowite zanurzenie w naturze, w rezultacie pozwalające na głęboki i osobisty kontakt dziecka z przyrodą, doświadczenie spontanicznej i naturalnej nauki w sposób pozytywny ingerującej w jego rozwój. Mali podopieczni leśnych placówek spędzają około $80 \%$ dziennego czasu na świeżym powietrzu, oddając się zabawie i nauce w naturalnym otoczeniu.

Popularność leśnych przedszkoli wzrasta na całym świecie. W Polsce tego rodzaju placówki powstały w Krakowie, Warszawie, Trójmieście i na Podlasiu. Na otwarcie czekają kolejne. W 2016 roku powstał w Białymstoku Polski Instytut Przedszkoli Leśnych. Jego celem jest wspieranie podobnych inicjatyw i standaryzacja oddziaływań edukacyjnych poprzez certyfikację działających placówek. Elementami składowymi tego typu przedszkoli jest niewielki fragment lasu, barakowóz lub jurta, niewielka szopa, zaimprowizowana toaleta, natomiast najważniejszą składową są pełni wiary w swoje możliwości, entuzjastyczni wychowawcy.

\section{Edukacja przez kontakt $\mathrm{z}$ naturą}

Promowanie edukacji i kontaktu dzieci z naturą podczas pobytu w placówce jest nadrzędnym celem statutowym każdego leśnego przedszkola. Edukacja i wychowanie mają na celu nauczenie szacunku do przyrody i zbudowanie więzi z otaczającym światem. Więź ta ma fundamentalne znaczenie dla poczucia zakorzenienia wżyciu i umiejętności nadawania sensu własnej egzystencji. W sposób bezpośredni przekłada się na postrzeganie siebie jako istoty żyjącej i życzliwy stosunek do środowiska naturalnego jako żyjącego ekosystemu.

Rozwój dziecka ma charakter całościowy. Koncepcja leśnego przedszkola szczególnie artykułuje cele edukacyjne, takie jak kształtowanie u dziecka świadomości swego ciała poprzez zagwarantowanie mu swobody aktywności. 
Znaczenie pojęcia ruchu w rozwoju dziecka jest kluczowe. Uzewnętrznienie myśli i uczuć w przypadku dzieci następuje w kontakcie z otoczeniem podczas ruchu. Można powiedzieć, że u dzieci mamy do czynienia z behawioralną ekspresją emocji. Ponadto dowolność w wyborze formy ruchu, doświadczenie jej różnorodności, na przykład podczas biegania po naturalnej, nierównej nawierzchni zawierającej wiele przeszkód w postaci kamieni, dziur czy też gałęzi, znakomicie rozwija ogólną motorykę dziecka (Janik, 2015, s. 136).

Edukacja w kontakcie z przyrodą służy powiązaniu wszystkich zmysłów dziecka. Ich aktywizacja jest wynikiem różnorodności doświadczeń i pozwala na sensoryczne budowanie obrazu świata. Podejmowanie twórczego trudu samodzielnej organizacji przestrzeni zabawy wyzwala pomysłowość, a poprzez urozmaiconą aktywność ułatwia nabywanie i zwiększenie świadomości własnego ciała. Różnorodność i bogactwo darów natury istotnie wpływa na stymulowanie zmysłów dzieci. Dziecięce ucho rejestruje wiele dźwięków i odgłosów, takich jak: śpiew ptaków, szelest liści, dźwięk szumiącego wiatru między drzewami lub ulewy. Wzrok i dotyk dziecka karmi się różnorodnością faktur: ostrych szyszek, kolczastych krzewów, włochatych gąsienic czy miękkiego mchu. Nos dziecka rejestruje i rozpoznaje wiele zapachów: zapach lasu po deszczu, zapach poziomek bądź poszczególnych rodzajów ziól. Zmysły dziecka rozpoznają zmienność temperatury powietrza, jakim będzie chłód poranka, ciepło słońca będącego w zenicie, wilgotność mgły czy też zimowego mrozu. Wrażliwość i integralność sensoryczna odgrywa istotną rolę w poczuciu szczęścia, gdyż wiąże się z umiejętnością smakowania życia.

Istotnym celem edukacji $\mathrm{w}$ ramach leśnego przedszkola jest zapoznanie dziecka z rytmem i życiem natury. Definicja natury w najprostszym przełożeniu rozumiana jest jako źródło powietrza czy też żywności, jest egzystencjalną podstawą życia człowieka, będącą balansem dla życia w mieście. Las jest środowiskiem życia dzieci i miejscem kontaktu z przyrodą, czego owocem jest przyjazne nastawienie do natury. Przestrzeń leśnego przedszkola stwarza liczne możliwości nauki przez naśladownictwo. Rola nauczycieli w tym wypadku jest nietypowa - polega na zapewnieniu swobody dzieciom i sporadycznych interwencjach w ich zabawę. Celem, jaki stawiają sobie tego rodzaju przedszkola, jest praca zgodna z rytmem natury. Powtarzalność i cykliczność pór dnia i roku, świąt i festiwali reguluje poczucie bezpieczeństwa u dzieci oraz wzmacnia we wspólnych doświadczeniach (Janik, 2015, s. 136-137).

Ważnym założeniem jest zgoda na to, aby dzieci mogły podejmować własne decyzje. Dzieci w ramach zajęć świadomie biorą udział w kształtowaniu swojego środowiska, są autorami własnej aktywności, wymyślają zabawy, co pozwala traktować je jako osoby samodzielne i odpowiedzialne. 
Przestrzeń środowiska wspomaga poczucie pewności siebie i służy nabyciu umiejętności samodzielnego zaspokojenia własnych potrzeb. Przedszkole uczy także samodyscypliny, czego przykładem może być przestrzeganie zasady milczenia w czasie obserwacji przyrody, stwarza okazję do ćwiczeń rozwijających koncentrację, zmierzających do samoopanowania, uzyskania wewnętrznego spokoju.

Realizacja zasady wzmacniania własnych sił, w holistycznym ujęciu rozwoju dzieci, wymaga odpowiednich warunków do zdobywania doświadczeń ruchowych, psychicznych, duchowych, społecznych i emocjonalnych służących dobremu samopoczuciu. Codzienna zabawa na świeżym powietrzu ma na celu wzmacnianie dziecięcej odporności. Rozwój umiejętności komunikacyjnych i społecznych służy kształtowaniu poczucia wspólnoty. Obchodzenie świąt i festynów bądź wspólne przygotowywanie posiłków pobudza u dzieci poczucie autonomii, a jednocześnie przynależności do grupy. Istotne jest wzajemne słuchanie, umiejętność rozwiązywania konfliktów, dostrzeganie własnych i cudzych potrzeb, odczytywanie i wyrażanie emocji, a także współpraca. Celem leśnych przedszkoli jest wprowadzenie dzieci do świata gier i zabaw w przestrzeni lasu, który daje wiele możliwości, jednocześnie będąc doskonale wyposażoną „pracownią”. Rzeczywistość tego typu placówek wpisuje się w wielowymiarową aktywność dzieci w przyrodzie, wspomaga rozwój dużej i małej motoryki, na przykład w trakcie zabawy z kamieniami, gałęziami, mchem bądź szyszkami. Istotą tego rodzaju ćwiczeń jest wzbudzenie potrzeby bezpieczeństwa $\mathrm{w}$ ruchu. Bezpieczne poruszanie się $\mathrm{w}$ trakcie wycieczek poza przedszkolem znajdzie swoje przełożenie podczas poruszania się w ruchu drogowym. Celem konstruowania i wykorzystywania własnych instrumentów i narzędzi podczas zabaw jest kształtowanie twórczej wyobraźni i wszechstronny rozwój. W trakcie wszystkich tych aktywności rozwija się pomysłowość dziecka i pobudza się jego ciekawość w czasie eksploracji otoczenia i zabaw. Edukacja matematyczna odbywa się poprzez analizę codziennych doświadczeń podczas dokonywania rzeczywistych pomiarów i praktycznych obliczeń (Janik, 2015, s. 137-138). Wczesna edukacja może być jednocześnie zdrowa i ekscytująca, spełniając przy tym wszystkie obecnie obowiązujące standardy edukacyjne.

Leśne przedszkola są odpowiedzią na problemy współczesnego dzieciństwa i wyzwań jakie ono stawia, w odniesieniu do dynamicznego rozwoju cywilizacji, niewpływającego pozytywnie na ogólny rozwój dziecka. Są obiecującą perspektywą i alternatywą dominującej pedagogiki przedszkolnej. Urbanizacja, industrializacja i informatyzacja oraz towarzyszące im przemiany społeczne prowadzą do zakłóceń i zniekształceń możliwości sensorycznego 
doświadczania świata u dzieci i zaburzają ich prawidłowy rozwój psychofizyczny. Leśne przedszkola zapewniają dzieciom „naturalne” dzieciństwo, pełne zabaw, polisensorycznych doświadczeń, stwarzają warunki fizycznego i emocjonalnego kontaktu z przyrodą oraz bezpośredniego przeżywania pór roku. Różnorodność zjawisk przyrodniczych, bogactwo barw i kształtów rozbudza ciekawość świata. W takich okolicznościach dzieci chętnie szukają odpowiedzi na pytania, które podsuwa im otaczająca je natura. Jest to dobra, wręcz konieczna do wykorzystania okazja, wspierająca ogólny rozwój małego człowieka, bowiem „dzieci na całym świecie tracą kontakt z przyrodą - lepiej rozpoznają zwierzęta z egzotycznych krajów i z bajek, niż te żyjące w ich najbliższym sąsiedztwie. Naukowcy biją na alarm, bo szkodzi to i dzieciom, i ochronie przyrody" (Janik, 2015, s. 137-138).

Lasy są szczególnym elementem krajobrazu, pełnią funkcje, które gwarantują w znacznym stopniu prawidłowe stosunki w krajobrazie. Modyfikują klimat, wpływając również na sąsiadujące pola, osiedla, a nawet większe miasta. W lesie panują znacznie mniejsze amplitudy temperatur. Dzięki temu w upalne dni można odczuć tam przyjemny chłód. Roślinność i drzewa stanowią barierę przed chłodem dnia i wiatrem, dając wrażenie ciepła (Stępczak, 1998).

Las to najwłaściwsze miejsce do relaksu, fizycznego i psychicznego, odprężenia oraz odpoczynku w stanach ogólnego zmęczeniu, zwłaszcza związanego z uciążliwością trybu życia. Szczególnie wskazane jest przebywanie w lesie po okresach obarczonych dużym napięciem nerwowym; na całym świecie funkcjonują ośrodki sylwoterapii wspomagające leczenie chorób cywilizacyjnych (Byeongsang $\mathrm{i}$ in., 2017).

\section{Próba krytycznego spojrzenia}

Założyciele leśnych przedszkoli czerpią z bogactwa pedagogiki alternatywnej, w tym koncepcji weryfikowanych empirycznie. Jak pisze Urszula Ordon:

niezależnie od wykorzystywanych koncepcji - montessoriańskiej, flow learning czy waldorfskiej - organizatorzy i beneficjenci przedszkoli leśnych podkreślają pozytywny wpływ procesu wychowania realizowanego w lesie na fizyczny, psychiczny i społeczny rozwój dziecka. W pierwszym wymienionym obszarze odnotowuje się: dobry rozwój motoryki, mniejszą niż w populacji dzieci z przedszkoli tradycyjnych liczbę przedszkolaków z wadami postawy i wzroku oraz wyższą odporność. W zakresie rozwoju psychicznego „dzieci leśne” przejawiają wyższe zdolności logicznego przewidywania skutków swoich działań, dostrzegają związki przyczynowo-skutkowe obserwowanych zjawisk, wykazują zdolność koncentracji, mają też lepiej rozwiniętą zdolność oceny ryzyka w otoczeniu. W obszarze zaś działań społecznych wychowanie na łonie przyrody w miesza- 
nych wiekowo grupach sprzyja rozwijaniu zdolności komunikacyjnych, empatii, rozwiązywaniu problemów, wytrwałości w wykonywaniu zadań, współdziałaniu, nawiązywaniu przyjaźni (Ordon, 2019, s. 120).

Warto jednak zauważyć, że o leśnych przedszkolach piszą głównie entuzjaści, brak jest na gruncie polskim badań empirycznych nad efektami tej formy edukacji. W literaturze przedmiotu można znaleźć odwołania do nielicznych badań brytyjskich, na przykład Richarda Murraya i Liz O’Brien (2004, 2005) oraz Janine Coates i Helen Pimlott-Wilson (2018).

Aby przyjrzeć się efektom alternatywnych form edukacji z nurtu nowej pedagogiki, proponuję dokonanie pewnego zabiegu. Leśne przedszkola mają wiele wspólnych założeń programowych z pedagogiką montessoriańską. Magdalena Christ i Agata Preuss (2018) wyodrębniły osiem takich elementów. Są one zbieżne także z założeniami przedszkoli waldorfskich (por. Kiersch, 2008):

1. Grupy są mieszane wiekowo (3-6 lat).

2. Wychowanie to rozpoznawanie, obserwowanie i wspieranie dziecka w rozwoju.

3. Szacunek do emocji dziecka, jego potrzeb i działań. Empatyczna komunikacja.

4. Bliski kontakt $\mathrm{z}$ naturą. Uwrażliwianie na piękno przyrody.

5. „Lekcje ciszy”. Kontrola ruchu, ruch medytacyjny. Twórcza ekspresja ruchowa.

6. Rezygnacja $\mathrm{z}$ tradycyjnych zabawek.

7. Przyzwolenie na popełnianie błędów bez obarczania obawą o krytykę.

8. Forma spędzania czasu - wiele rzeczy dzieje się równolegle.

Zakładam, że zastosowanie tych zasad w praktyce różnicuje efekty kształcenia w stosunku do tradycyjnego modelu edukacji w zbliżony sposób. Proponuję przyjrzenie się wynikom polskich badań dotyczących szkół waldorfskich. W roku 2016 Magdalena Ostolska obroniła rozprawę doktorską przygotowaną pod kierunkiem prof. Bogusława Śliwerskiego pod tytułem Efekty wychowania $w$ szkołach waldorfskich $w$ Polsce. Mimo że praca nie doczekała się publikacji książkowej, wyniki zawartych w niej badań zostały zaprezentowane przez prof. Śliwerskiego na jego blogu. I tak

w zakresie rozwoju społecznego, mimo że więcej punktów zdobyli uczniowie waldorfscy, uczniowie szkół ogólnodostępnych wypadają korzystniej w zagadnieniach związanych z postawą patriotyczną i prospołeczną. Uczniowie szkół 
ogólnodostępnych są też mniej egocentryczni i bardziej skłonni do poświęceń na rzecz innych. Osiągają również lepsze noty w zakresie rozumienia znaczenia kultury osobistej i w zakresie stosunku do nauki.

Dzieci „waldorfskie” potrafią lepiej i świadomiej dbać o swoje zdrowie, są nieco bardziej kreatywne i mają wyższą samoocenę w porównaniu z dziećmi ze szkół ogólnodostępnych. Mają jednak dużo mniejsze zaufanie do rodziców niż uczniowie w szkołach ogólnodostępnych. Praca nad emocjami jest codziennością szkół waldorfskich. Szkoły publiczne wpajają zasady zachowania.

Sama emocjonalność uczniów nie jest jednak przedmiotem działań wychowawczych. Uczniowie szkół waldorfskich akceptują szkołę na dużo wyższym poziomie niż uczniowie szkół ogólnodostępnych. Wszystkie wskaźniki z tego zakresu uzyskują konsekwentnie więcej punktów niż w szkołach ogólnodostępnych. Ponad $72 \%$ uczniów steinerowskich odpowiedziało twierdząco na pytanie: „Czy lubisz przebywać w szkole?”, i nikt nie wskazał odpowiedzi negatywnej. Wśród uczniów szkół ogólnodostępnych tylko 50\% akceptuje szkołę, a ponad 23\% całkowicie ją odrzuca (Śliwerski, 2016).

Wyniki badań Magdaleny Ostolskiej ujawniają podstawowe ograniczenie związane z kształceniem $\mathrm{w}$ alternatywnej placówce edukacyjnej tego typu: trudność w zrównoważeniu rozwoju osobistego i edukacji prospołecznej. Brak jest, niestety, naukowych opracowań dotyczących funkcjonowania społecznego i kariery absolwentów szkół z nurtu nowej pedagogiki. W przypadku absolwentów leśnych przedszkoli dodatkowy problem może stanowić konieczność kontynuacji nauki w tradycyjnej szkole i związany z tym stres adaptacyjny. Jak zauważa Bogusław Śliwerski (2016), szkoła waldorfska „chce chronić dziecko podczas jego pierwszych kroków w samodzielność. Szkoły ogólnodostępne przyjmują przeciwną strategię. Tu dzieci mają się nauczyć odpowiadać na wyzwania codzienności, by późniejsze zmagania z życiem nie były dla nich nowością".

Podejścia antropo- i socjocentryczne w edukacji nie wykluczają się wzajemnie, człowiek jest istotą społeczną. Sztuka wychowania wymaga prowadzenia wychowanków „środkową drogą”.

\section{Podsumowanie}

Leśne przedszkola są cenną inicjatywą edukacyjną, dającą możliwość wszechstronnego rozwoju dzieci przy twórczym wykorzystaniu środowiska naturalnego. Relacja ze światem przyrody jest ważnym elementem wychowawczym, kształtującym postawę proekologiczną. Pozytywne efekty nauki w leśnych przedszkolach i szkołach stanowią zachętę do podejmowania inicjatyw edukacyjnych poszerzających relację dziecka ze światem przyrody, także w tradycyjnym modelu kształcenia. Istnieje potrzeba pogłębionych badań nad przesłankami, warunkami i efektami edukacji w tego typu placówkach. 
Może się okazać, że w niedalekiej przyszłości, w warunkach wysokorozwiniętej cywilizacji technicznej, leśne przedszkola staną się swoistym przywilejem jako optymalna forma wspierania wczesnego rozwoju kolejnych pokoleń, pozwalająca im zachować łączność ze światem natury.

\section{BIBLIOGRAFIA}

Byeongsang O. i in. (2017). Health and well-being benefits of spending time in forests: systematic review. Environmental Health and Preventive Medicine, 22 (1), 22-71.

Christ, M., Preuss, A. (2018). Związek leśnych przedszkoli z metodą Marii Montessori. Edukacja Elementarna w Teorii i Praktyce, 1.

Chrzanowski, T. (2003). Edukacja leśna w pracy leśniczego. Warszawa: Centrum Informacyjne Lasów Państwowych.

Chrzanowski, T. (2003). Wytyczne do tworzenia programu edukacji leśnej społeczeństwa w nadleśnictwie. Warszawa: Centrum Informacyjne Lasów Państwowych.

Coates, J.K., Pimlott-Wilson, H. (2018). Learning while playing: Children's Forest School Experiences in UK. Pozyskano z: https://onlinelibrary.wiley.com/doi/abs/10.1002/berj.3491, [data dostępu: 10.05.2020].

Czub, M., Appelt, K. (2013). Wczesna edukacja i opieka nad małym dzieckiem jako wyzwanie dla systemu edukacji. Studia Edukacyjne, 27.

Jakubowska, J. (2008). „Osuszek” - program edukacji leśnej dla klas I-III szkoły podstawowej. Warszawa: Centrum Informacyjne Lasów Państwowych.

Janik, A. (2015). Koncepcja pedagogiczna i program leśnych przedszkoli na przykładzie przedszkola w Lipsku na terenie Niemiec. Problemy Wczesnej Edukacji, 4 (31).

Louv, R. (2014). Ostatnie dziecko lasu. Jak chronić nasze dzieci przed zespołem deficytu natury. Warszawa: Wydawnictwo Relacja.

Murray, R. (2004). Forest School Evaluation Project: A Study in Wales. Report carried out by New Economics Foudation (NEF). Pozyskano z: www.neweconomics.com, [data dostępu: 20.04.2019].

Murray, R., O’Brien, L. (2005). Such Enthusiasm - a Joy to See: An Ewaluation of Forest School in England. Report carried out by New Economics Foudation (NEF). Pozyskano z: www. neweconomics.org, [data dostępu: 20.04.2019]

Muszyński, M. (2014). Edukacja i uczenie się - wokół pojęć. Rocznik Andragogiczny, 21.

Poskrobko, B. (red.). (1998). Naturalne środki dydaktyczne. Białystok: Dział Wydawnictw i Poligrafii Politechniki Białostockiej.

Okoń, W. (1996). Wprowadzenie do dydaktyki ogólnej. Wyd. 3. Warszawa: Wydawnictwo Akademickie Żak.

Ordon, U. (2019). Przedszkola leśne a potrzeba edukacji zdrowotnej i ekologicznej wśród najmłodszych. Edukacja Elementarna w Teorii i Praktyce, t. 14, 3 (53), 111-121.

Potulicka, E. (2014). Rynkowy model wczesnej edukacji a stanowisko profesjonalistów - perspektywa globalna. Problemy Wczesnej Edukacji, t. 10, 3 .

Skubała, P. (1995). Wychowanie ekologiczne w przedszkolu. Wychowanie w Przedszkolu, 8, 458-465.

Sonelski, W., Magiera, A. (2016). Polskie koncepcje i programy wychowania przez przygodę. Wybrane przykłady z pierwszej połowy XX wieku. Kwartalnik Pedagogiczny, 2 (240), 185-202.

Śliwerski, B. (2016). Efekty wychowania w szkołach waldorfskich. Pozyskano z: https://sliwerski-pedagog.blogspot.com/2016/og/efekty-wychowania-w-szkoach.html, [data dostępu: 11.05.2020].

Śliwerski, B. (2010). Pedagogika alternatywna. W: B. Śliwerski (red.), Pedagogika (t. 4: Subdyscypliny i dziedziny wiedzy o edukacji). Gdańsk: GWP. 
Tuszyńska, L. (2006), Edukacja ekologiczna. Warszawa: Wydawnictwo Wyższej Szkoły Pedagogicznej TWP.

Zalewska, S. (2018). Koncepcje i zasady kształcenia alternatywnego. Pozyskano z: https://www. gimversity.pl/files/document/7faaa877292d61e656c8682b992be2941388743309.pdf, [data dostępu: 29.01.2019].

Zamojska, E. (2012). Alternatywność i innowacyjność w edukacji współczesnej - na przykładzie Czech. Kultura - Społeczeństwo - Edukacja, 1, 105-119.

\section{SUMMARY}

\section{Forest kindergarten as an alternative form of preschool education}

Forest kindergartens are an alternative form of preschool education which takes place in forest environment with the use of available, natural educational materials. Thanks to the close contact and interaction with nature, children develope their motor skills, polysensory sensitivity, creativity, self-discipline, ability to cooperate and observe in both critical and contemplative way. The purpose of this paper is to encourage educators to reflection on searching forms of education that broadens the child's relationship with the world of nature.

KEYWORDS: preschool education, nature, child, forest 